\title{
Initial Development of Cowpea Bean Fertilized with Natural Phosphate in the Brazilian Cerrado Soil
}

\author{
Edna Maria Bonfim-Silva*, Denise César Soares, Paula Caroline Lima Silva, \\ Ana Paula Alves Barreto Damasceno, Tonny José Araújo da Silva, \\ Helon Hébano de Freitas Sousa
}

Department of Agricultural and Environmental Engineering, Institute of Agricultural Sciences and Technology, Federal University of Mato Grosso, Cuiabá, Brazil

Email: *embonfim@hotmail.com

How to cite this paper: Bonfim-Silva, E.M., Soares, D.C., Silva, P.C.L., Damasceno, A.P.A.B., da Silva, T.J.A. and Sousa, H.H.F. (2018) Initial Development of Cowpea Bean Fertilized with Natural Phosphate in the Brazilian Cerrado Soil. American Journal of Plant Sciences, 9, 1381-1390.

https://doi.org/10.4236/ajps.2018.97100

Received: May 2, 2018

Accepted: June 5, 2018

Published: June 8, 2018

Copyright $\odot 2018$ by authors and Scientific Research Publishing Inc. This work is licensed under the Creative Commons Attribution International License (CC BY 4.0).

http://creativecommons.org/licenses/by/4.0/ c) (i) Open Access

\begin{abstract}
Cowpea, string Bean, or Macassar bean [Vigna unguiculata (L.) Walp] presents a short life cycle, low water requirement, develops in soils of low fertility, and has the ability to fix nitrogen from the air. In the Cerrado, the oxisols occupy practically all the flat to soft-wavy areas with little reserve of nutrients for the plants, in general, they are soils with great limitations of fertility. A source of alternative phosphate fertilization is the use of reactive natural phosphates. The reactive natural phosphate of Bayóvar presents intermediate solubility between the sources of soluble phosphates and the natural phosphates. In this context, the objective was to evaluate the initial development of Cowpea beans fertilized with the natural Bayóvar phosphate used for cultivation of the Brazilian Cerrado Oxisol. The experimental design was completely randomized, with six doses of phosphorus $(0,100,200,300,400,500$ $\mathrm{mg} \cdot \mathrm{dm}^{-3}$ ) using natural Bayovar phosphate as a source in four replications. The species used in this study was the legume cowpea bean [Vigna unguiculata (L.) Walp] cultivar Tumucumaque. The treatments were applied using the natural phosphate Bayóvar as a source of phosphorus $\left(29 \%\right.$ of $\left.\mathrm{P}_{2} \mathrm{O}_{5}\right)$. At 33 DAS (days after sowing), the variable number of leaves of the Cowpea bean was analyzed and at 40 DAS, the variables plant height, SPAD chlorophyll index (Soil Plant Analysis Development) and stem diameter were analyzed. For all variables analyzed there was a significant effect. The initial development of the cowpea bean cultivated in the Brazilian Cerrado Oxisol was significantly influenced by the Bayóvar natural phosphate fertilization with the best phosphorus $\left(\mathrm{P}_{2} \mathrm{O}_{5}\right)$ doses in the range of 200 to $350 \mathrm{mg} \cdot \mathrm{dm}^{-3}$.
\end{abstract}




\section{Keywords}

Vigna unguiculata (L.) Walp, Phosphate of Bayóvar, Oxisol

\section{Introduction}

Cowpea, string Bean, or Macassar bean [Vigna unguiculata (L.) Walp] is an excellent source of protein (23\% to $25 \%$ on average) and contains all essential amino acids, carbohydrates (62\% on average), vitamins and minerals, as well as a large amount of dietary fiber and low amount of fat (oil content of $2 \%$ on average). It serves as basic food for the low-income populations of the Brazilian Northeast. It presents a short life cycle, low water requirement, develops in soils of low fertility, and has the ability to fix nitrogen from the air, through symbiosis with bacteria of the genus Rhizobium [1].

The author [2] reported that in 2016, Brazil produced 344,752 t harvested in $1,066,175$ hectares, with an average yield of $323 \mathrm{~kg} \cdot \mathrm{ha}^{-1}$. This production places Brazil as the fourth largest producer in the world. The largest Brazilian producers in 2017 were the States of Mato Grosso $(134,814$ t), Ceará $(55,278$ t), Maranhão $(34,934$ t), Pernambuco $(25,153$ t), Piauí (21,959 t) and Pará $(20,289$ t). Piauí showed the lowest grain yield, with $134 \mathrm{~kg} \cdot \mathrm{ha}^{-1}$, while Mato Grosso, recorded the highest productivity, with $869 \mathrm{~kg} \cdot \mathrm{ha}^{-1}$.

Cowpea beans are grown mainly in the semi-arid interior of the Northeast and in small areas in the Amazon. In these regions, traditional practices of cultivation still predominate, with low use of technologies and low grain yields. However, with the advent of technologies that allow its fully mechanized cultivation, there has been an increase in the area of cultivation, production and productivity in the Midwest region, notably in the State of Mato Grosso. In this state, the reality is different, cowpea is cultivated on a large scale, with the participation of medium and large producers, presenting the highest yields of grains [1].

In the Cerrado, the oxisols occupy practically all the flat to soft-wavy areas with little reserve of nutrients for the plants, usually represented by their low to average cation exchange capacity. More than $95 \%$ of the dystrophic and acidic Oxisol, have $\mathrm{pH}$ between 4.0 and 5.5 and extremely low available phosphorus levels, almost always inferior to $1 \mathrm{mg} \cdot \mathrm{dm}^{-3}$. In general, they are soils with great limitations of fertility [3].

As a result of its participation in the so-called energy-rich compounds, such as adenosine triphosphate (ATP), phosphorus plays a fundamental role in plant life, being essential in cell division, reproduction and plant metabolism such as photosynthesis, respiration and the synthesis of organic substances [4]. In cowpea beans, phosphorus extraction occurs in a smaller quantity when compared to other macronutrients, but it is the nutrient that most limits its productivity [5].

In order to guarantee a good agricultural production in the Cerrado, due to 
the low availability of phosphorus and its dynamics in the soil, fertilization with high doses of phosphorus is required, and this results to a great increase in production costs [6].

A source of alternative phosphate fertilization is the use of reactive natural phosphates, which, although undergo solubilization more slowly in the soil compared to industrial fertilizers, are a lower cost alternative for phosphorus fertilization because they are ores with less industrial processes [7].

The reactive natural phosphate of Bayóvar presents intermediate solubility between the sources of soluble phosphates and the natural phosphates. It is a phosphate of sedimentary origin and is characterized to present a high degree of isomorphic substitution of the phosphate ion by carbonate, which gives it a higher rate of reaction in the soil when compared to other natural phosphates [7].

In this context, the objective was to evaluate the initial development of Cowpea beans fertilized with the natural Bayóvar phosphate used for cultivation of the Brazilian Cerrado Oxisol.

\section{Methodology}

The experiment was conducted in a greenhouse at the Federal University of Mato Grosso ( $16^{\circ} 27^{\prime}$ South latitude, $54^{\circ} 34^{\prime}$ West longitude and 284 meters altitude), Campus Universitário de Rondonópolis. The climate of the region is Aw, according to the classification of Köppen, with rainy summer and long periods of drought during the year. The average annual temperature was $24.8^{\circ} \mathrm{C}$. The soil used was the Red Oxisol [8], collected in an area under the Cerrado vegetation at a depth of 0 to $0.20 \mathrm{~m}$ and sieved using a $2 \mathrm{~mm}$ mesh sieve for chemical and granulometric characterization (Table 1) and in a sieve of $4 \mathrm{~mm}$ mesh for filling pots for growing. The vases utilized were $3.7 \mathrm{dm}^{-3}$.

The experimental design was completely randomized, with six doses of phosphorus $\left(0,100,200,300,400,500 \mathrm{mg} \cdot \mathrm{dm}^{-3}\right)$ using natural Bayovar phosphate as a source in four replications.

The species used in this study was the legume cowpea bean [Vigna unguiculata (L.) Walp] cultivar Tumucumaque. The soil was corrected by increasing the base saturation to $60 \%$ using calcareous dolomite $(28 \% \mathrm{CaO}$ and $20 \% \mathrm{MgO})$ and Total Neutralizing Power of $80.3 \%$. After the incorporation of limestone, the soil was incubated for 20 days with the humidity maintained at $60 \%$ of its maximum soil retention capacity, using the gravimetric method [9].

After the incubation period of the calcareous soil, the treatments were applied

Table 1. Chemical and granulometric analyses of Red Oxisol collected under the Cerrado vegetation of the $0-0.20 \mathrm{~m}$ layer.

\begin{tabular}{|c|c|c|c|c|c|c|c|c|c|c|c|c|c|}
\hline $\mathrm{pH}$ & $\mathrm{P}$ & K & $\mathrm{Ca}$ & $\mathrm{Mg}$ & $\mathrm{H}$ & $\mathrm{Al}$ & SB & CEC & $\mathrm{V}$ & O.M. & Sand & Silt & Clay \\
\hline $\mathrm{CaCl}_{2}$ & $\mathrm{mg} \cdot \mathrm{d}$ & $\mathrm{m}^{-3}$ & --- & ----. & $----c$ & olc.d & 3--.. & ---- & $\%$ & $\mathrm{gd} \cdot \mathrm{m}^{-3}$ & ------ & $\cdot \mathrm{kg}^{-1}$ & ----- \\
\hline 4.0 & 1.4 & 23 & 0.4 & 0.2 & 5.4 & 0.8 & 0.7 & 6.8 & 9.7 & 27.1 & 423 & 133 & 444 \\
\hline
\end{tabular}


using the natural phosphate Bayóvar as a source of phosphorus (29\% of $\left.\mathrm{P}_{2} \mathrm{O}_{5}\right)$. Potassium fertilization $\left(\mathrm{K}_{2} \mathrm{O}\right)$ of $80 \mathrm{mg} \cdot \mathrm{dm}^{-3}$ was used as the source of potassium chloride and micronutrients with $15 \mathrm{mg} \cdot \mathrm{dm}^{-3}$ of FTE (Fritted Trace Elements), in all treatments. Thereafter, sowing was done, and 5 seeds were arranged per pot, and after seven days thinning was done, leaving only two plants per pot.

At 33 DAS (days after sowing), the variable number of leaves of the Cowpea bean was analyzed and at $40 \mathrm{DAS}$, the variables plant height, SPAD chlorophyll index (Soil Plant Analysis Development) and stem diameter were analyzed.

The number of leaves was obtained by counting in each vase. The height of plants was measured with a graduated ruler, from the soil to the apex of each plant present in the vase, with an average to compose the height of the plot. The chlorophyll index was determined using the Minolta SPAD-502 chlorophyll meter. For the determination of the diameter of the stem an analog pachymeter was used at a height $2 \mathrm{~cm}$ from the soil surface.

The results were submitted to regression analysis and significance was determined at 5\% error of probability, using the statistical program Sisvar [10].

\section{Results and Discussion}

\subsection{Plant Height}

For the variable plant height in the Cowpea beans, there was a significant effect as a function of the phosphorus doses, adjusting to the quadratic regression model. The dose of phosphorus $\left(\mathrm{P}_{2} \mathrm{O}_{5}\right)$ that provided higher plant height $(42.62$ $\mathrm{cm}$ ) was $276.7 \mathrm{mg} \cdot \mathrm{dm}^{-3}$, with an increase of $22.95 \%$ when compared to the absence of phosphate fertilization (Figure 1).

Based on the results, it is possible to observe the importance of phosphorus to the crop, which has limited growth due to the low amount of phosphorus available

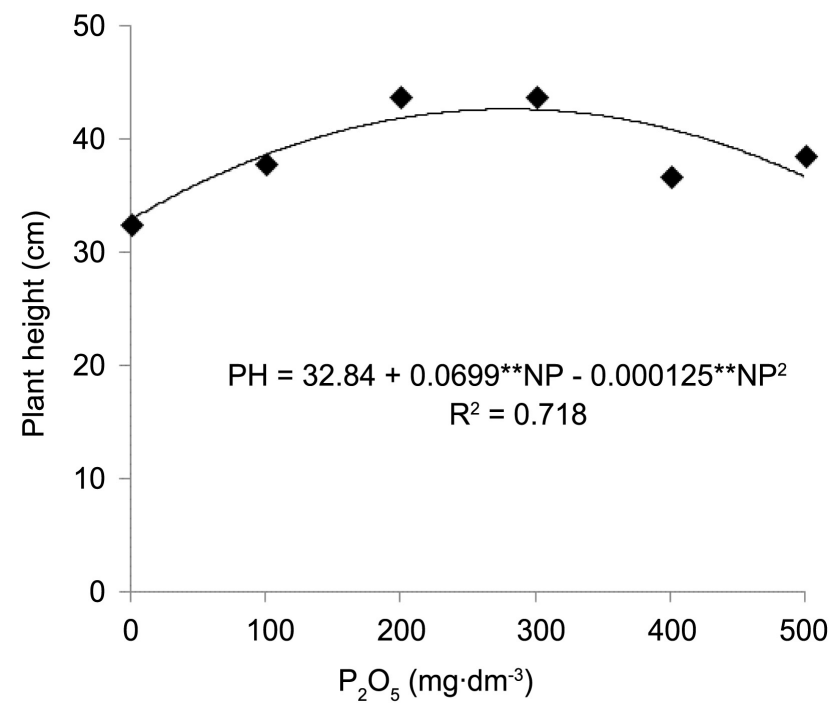

Figure 1. Height of cowpea beans at the 40 days after sowing doses of natural phosphate $\left(\mathrm{P}_{2} \mathrm{O}_{5}\right)$. PH: Plant height; NP: Natural phosphate doses. ${ }^{*}$ Significant at $1 \%$ error probability. 
in the soil. The plants present several ways of alleviating the problems caused by phosphorus deficiency, such as reducing growth, which reduces the need for phosphorus for the processes that require energy and carbon skeletons, thus, the requirement of phosphorus also reduces [11] [12].

The authors [13] in a study on the effect of residual phosphorus on Cowpea bean cultivated in Cerrado soil, verified that there was no significant effect on plant height, noting that phosphorus $\left(\mathrm{P}_{2} \mathrm{O}_{5}\right)$ doses above $200 \mathrm{~kg} \cdot \mathrm{ha}^{-1}$ are required. Phosphorus acts in the plant in several metabolic functions, acting also in the cellular division, thus the height of plants is an important variable to be studied as an indication of the quality and evolution of the crop [14].

The results observed in the present study corroborate those of [15], who in a study of doses of phosphorus in cowpea beans using triple superphosphate as a source, observed that for the plant height variable, the maximum value (26.86 $\mathrm{cm}$ ) was reached with a phosphorus $\left(\mathrm{P}_{2} \mathrm{O}_{5}\right)$ dose of $200 \mathrm{~kg} \cdot \mathrm{ha}^{-1}$, and higher cases recorded a lower plant height.

The authors [16] verified that the pigeon pea (Cajanus cajan) fertilized with natural phosphate also adjusted to the quadratic model with an increment of $41.34 \%$ in relation to the absence of phosphate fertilization.

\subsection{Number of Leaves}

The number of Cowpea leaves significantly increased with the phosphorus doses, adjusting to the quadratic regression model, the maximum value (18.32 leaves) was provided by the phosphorus $\left(\mathrm{P}_{2} \mathrm{O}_{5}\right)$ dose of $286.9 \mathrm{mg} \cdot \mathrm{dm}^{-3}$, presenting an increment of $47.16 \%$ of production in relation to the absence of phosphate fertilization (Figure 2).

In plants with phosphorus deficiency, there is an accumulation of this nutrient in organic compounds in the roots, which reduces transport to the aerial part and reduces its growth in relation to the root [11]. The increase in the number of

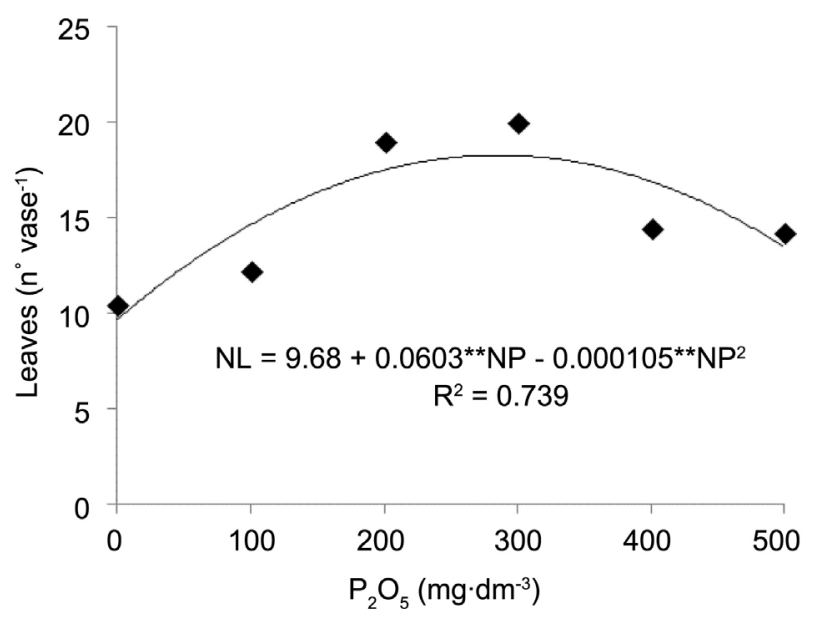

Figure 2. Number of cowpea bean leaves at the 33 days after seeded doses of natural phosphate $\left(\mathrm{P}_{2} \mathrm{O}_{5}\right)$. NL: Number of leaves; NP: Natural phosphate doses. ${ }^{*}$ Significant at $1 \%$ error probability. 
leaves causes an increase in the leaf area, which provides greater uptake of solar radiation and, consequently, greater photoassimilates production, allowing good plant development [17].

The authors [15], also verified increase in the number of leaves and quadratic response to the application of phosphorus $\left(\mathrm{P}_{2} \mathrm{O}_{5}\right)$, with maximum technical efficiency dose for $222.22 \mathrm{~kg} \cdot \mathrm{ha}^{-1}$, obtaining 24.71 leaves.

In other legumes such as java (Macrotyloma axillare), crotalaria (Crotalaria juncea) and pigeon pea (Cajanus cajan), an increase in phosphorus application was also observed compared to the treatment without phosphate fertilization [16] [17] [18]. This provides evidence of the need of phosphorus for the leguminous leaf area, among which is the Cowpea beans studied here.

The extraction of agronomic species influences the efficiency of phosphorus fertilization [19] [20]. In this context, the authors [21] reported that a determinant factor in the rationalization of phosphate fertilization is the adaptability to the tropical soils of the species to be cultivated, and is fundamental to define the degree of efficiency in the absorption of phosphorus by plants.

\subsection{Chlorophyll Index}

The chlorophyll content in the Cowpea bean plants, as a function of the phosphate fertilization $\left(\mathrm{P}_{2} \mathrm{O}_{5}\right)$, was adjusted to a quadratic model of regression as the maximum chlorophyll index of 54.33 was observed in the phosphorus dose of $266.12 \mathrm{mg} \cdot \mathrm{dm}^{-3}$, with an increase of $12.9 \%$, when compared to the dose that provided the maximum chlorophyll index in relation to the absence of phosphate fertilization (Figure 3).

The reading of the SPAD chlorophyll index is a method capable of evaluating the nutritional state of the plant, correlating the reading of the chlorophyll meter with the concentration of nitrogen in the plant [22] [23].

The authors [24] evaluated the effect of five doses and two sources of soluble

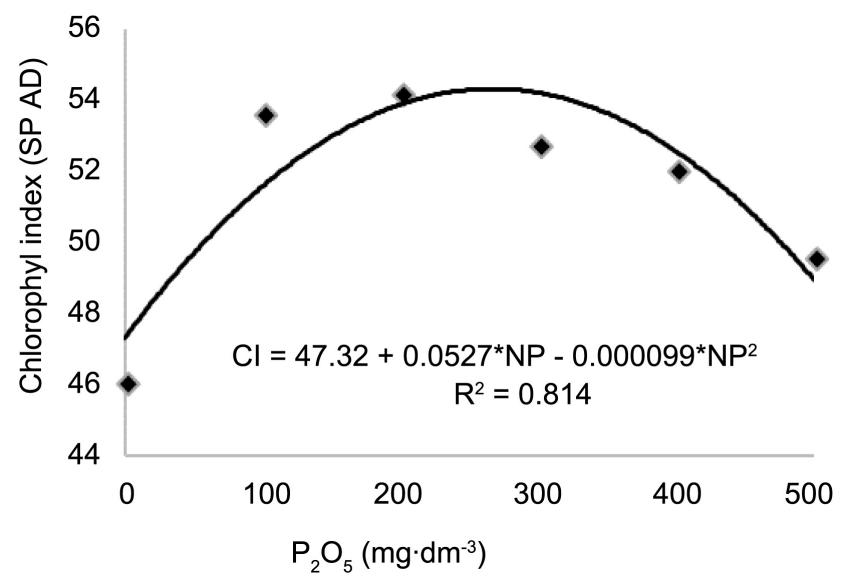

Figure 3. Chlorophyll content of cowpea beans at the 40 days after seeded doses of natural phosphate $\left(\mathrm{P}_{2} \mathrm{O}_{5}\right)$. CI: Chlorophyll Index; NP: Natural phosphate doses. ${ }^{\star}$ Significant at $5 \%$ error probability. 
phosphorus on the nodulation and biological fixation of $\mathrm{N}_{2}$ in cowpea beans, and found a quadratic response for the chlorophyll index with maximum values estimated for the reading of 41 and 56 units at phosphorus doses $\left(\mathrm{P}_{2} \mathrm{O}_{5}\right)$ of 66 and $86 \mathrm{~kg} \cdot \mathrm{ha}^{-1}$ for Single Super Phosphate and Triple Super Phosphate, respectively.

Phosphorus coordinates respiration, cell division, formation of proteins and starch. It is a component of nucleotides, such as ATP (adenosine triphosphate) that serve as the plant's main energy source. This energy is used in the transport of assimilates, energy storage and transfer, cell division, cell growth, and the transfer of genetic information [25]. Nitrogen assimilation is highly energy demanding, requiring two electrons and one ATP per molecule of $\mathrm{NH}_{4}^{+}$converted to glutamate [26]. In the same way, nitrate absorption impacts on the biological fixation of atmospheric $\mathrm{N}_{2}$ (is highly energy consuming) and of carbon skeletons produced by photosynthesis [11].

The authors [16] observed a linear response for the increase of the doses of phosphorus $\left(\mathrm{P}_{2} \mathrm{O}_{5}\right)$ in pigeon pea, reaching the maximum value with a dose of $600 \mathrm{mg} \cdot \mathrm{dm}^{-3}$. In the present study, it was possible to verify that phosphorus interferes with the chlorophyll index, which shows that there is interference in the assimilation of nitrogen by the cowpea bean plants up to the observed dose where it reaches its maximum value, however the excess causes a negative effect which reduces the chlorophyll index. Phosphorus is a very important nutrient in the process of biological nitrogen fixation and its low availability can lead to low efficiency of the plants in fixing atmospheric nitrogen.

\subsection{Stem Diameter}

The diameter of the cowpea bean stem as a function of the phosphate fertilization was adjusted to a quadratic regression model with the largest diameter of $4.75 \mathrm{~mm}$ observed in the phosphorus dose $\left(\mathrm{P}_{2} \mathrm{O}_{5}\right)$ of $307.6 \mathrm{mg} \cdot \mathrm{dm}^{-3}$, with an increase of $20 \%$ when compared to the dose that provided the largest stem diameter in relation to the absence of phosphate fertilization (Figure 4).

The authors [15] verified that the model that best fits the behavior of the stem diameter variable for the Cowpea bean crop, as a function of phosphate fertilization, was the linear one, obtaining in its work the highest value $(8.05 \mathrm{~mm})$ for the higher applied dose, $300 \mathrm{~kg} \cdot \mathrm{ha}^{-1} \mathrm{P}_{2} \mathrm{O}_{5}$ using the triple superphosphate source.

The results of the present study corroborate with the findings of other authors [16] [17] [27] who studied other legumes, java (Macrotyloma axillare), common bean (Phaseolus vulgaris) and pigeon pea (Cajanus cajan), and also observed an increase in the diameter of the stem with increasing doses of phosphorus.

The diameter of the stem is a very important variable, since the reduced growth in young plants and the production of thin (non-woody) stems are characteristic of phosphorus deficiencies in the plant [28]. In addition to presenting an important function in the mechanization process, the diameter of the larger stem promotes a better support of the plant, thus avoiding a high lodging index [27]. 


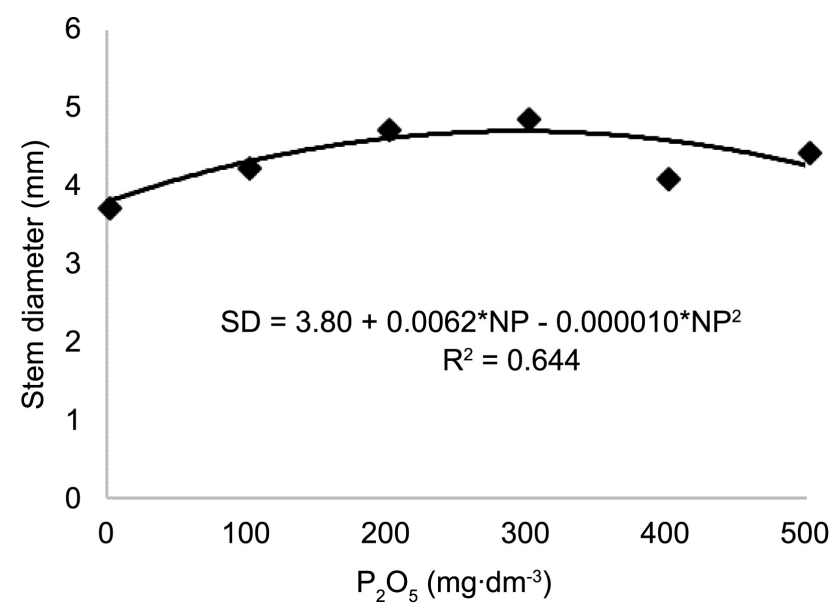

Figure 4. Stem diameter of cowpea bean at the 40 days after seeded doses of natural phosphate $\left(\mathrm{P}_{2} \mathrm{O}_{5}\right)$. SD: stem diameter; NP: Natural phosphate doses. ${ }^{*}$ Significant at $5 \%$ error probability.

\section{Conclusions}

The initial development of the cowpea bean cultivated in the Brazilian Cerrado Oxisol was significantly influenced by the Bayóvar natural phosphate fertilization with the best phosphorus $\left(\mathrm{P}_{2} \mathrm{O}_{5}\right)$ doses in the range of 200 to $350 \mathrm{mg} \cdot \mathrm{dm}^{-3}$.

The study proves that the use of a natural source of phosphorus as an alternative for phosphate fertilization, promoted significant influence on variables important for the good development of the studied crop.

\section{References}

[1] de Moura Rocha, M., e Silva, K.J.D. and de Menezes Junior, J.A.N. (2017) Cultivo de Feijão-Caupi. Importância econômica Versão Eletrônica. 2nd Edition. https://www.infoteca.cnptia.embrapa.br/infoteca/bitstream/doc/1071700/1/Sistema ProducaoCaupiCapituloImportanciaEconomica.pdf

[2] da Silva, O.F. (2017) Dados conjunturais da produção de feijão comum (Phaseolus vulgaris L.) e caupi (Vigna unguiculata (L.) Walp) no Brasil (1985 a 2016). Santo Antônio de Goiás: Embrapa Arroz e Feijão. http://www.cnpaf.embrapa.br/socioeconomia/index.htm

[3] de Sousa, D.M.G. and Lobato, E. (2018) Latossolos. Planaltina, DF: Embrapa Cerrados.

http://www.agencia.cnptia.embrapa.br/Agencia16/AG01/arvore/AG01_96_1011200 5101956.html

[4] Malavolta, E. (1985) Nutrição mineral. In: Ferri, M.G., Ed., Fisiologia vegetal, EPU, São Paulo, 97-116.

[5] Bemvindo, R.N. (2012) Adubação Fosfatada E potássica na nutrição e na produtividade de Feijão-Caupi, Cultivado no munícipio de Bom Jesus-PI. 61f. Tese (Doutorado em Agronomia) Produção Vegetal, Faculdade de Ciências Agrárias e Veterinárias-UNESP, Jaboticabal.

[6] Resende, A.V. and Furtinia, E. (2007) Aspectos relacionados ao manejo da adubação fosfatada em solos do cerrado. Planaltina, DF: Embrapa Cerrados. Documento $195,30 \mathrm{p}$. 
[7] Novais, R.F., Smyth, T.H. and Nunes, F.N. (2007) Fósforo. In: Novais, et al., Eds., Fertilidade do solo, Sociedade Brasileira de Ciência do Solo, Viçosa-MG, 470-550.

[8] EMBRAPA (Empresa Brasileira de Pesquisa Agropecuária) (2013) Sistema brasileiro de classificação de solos. Centro Nacional de Pesquisa de Solo. EMBRAPA-SPI, Rio de Janeiro.

[9] Bonfim-Silva, E.M., Silva, T.J.A., Cabral, C.E.A., Kroth, B.E. and Rezende, D. (2011) Desenvolvimento inicial de gramíneas submetidas ao estresse hídrico. Revista Caatinga, 24, 180-186.

[10] Ferreira, D.F. (2011) Sisvar: A Computer Statistical Analysis System. Ciência e Agrotecnologia, 35, 1039-1042. https://doi.org/10.1590/S1413-70542011000600001

[11] Vilar, C.C. and Vilar, F.C.M. (2013) Comportamento do fósforo em solo e planta. Revista Ciências Exatas e da Terra e Ciências Agrárias, 8, 37-44.

[12] Uhde-Stone, C., Gilbert, G., Johnson, J.M-F., Litjens, R., Zinn, K.E., Temple, S.J., Vance, C.P. and Allan, D.L. (2003) Acclimatation of White Lupin to Phosphorus Deficiency Involves Enhanced Expression of Genes Related to Organic Acid Metabolism. Plant and Soil, 248, 99-116. https://doi.org/10.1023/A:1022335519879

[13] da Costa Gaspar, J., Furtado, M.B., dos Santos Silva, W.J., dos Santos Reis, I., Machado, N.A.F., de Farias, M.F., Furtado, J.L.B., de Andrade, H.A.F., da Silva Sobral, R., Parra-Serrano, L.J., de Menezes Rodrigues, K. and Silva-Matos, R.R.S. (2018) Impacts of Residual Phosphorus on the Production of Cowpea in the Cerrado Region. American Journal of Plant Sciences, 9, 645-658. http://file.scirp.org/Html/11-2603617_82971.htm https://doi.org/10.4236/ajps.2018.94051

[14] Souto, J.S., Oliveira, F.T., Gomes, M.M.S., Nascimento, J.P. and Souto, P.C. (2009) Efeito da aplicação de fósforo no desenvolvimento de plantas de feijão guandu ( $\mathrm{Ca}$ janus cajan (L) Millsp) Revista Verde. Mossoró, 4, 135-140.

[15] Coutinho, P.W.R., Silva, D.M.S., Saldanha, E.C.M., Okumura, R.S. and Júnior, M.L.S. (2014) Doses de fósforo na cultura do feijão-caupi na região nordeste do Estado do Pará. Revista Agro-Ambiente, 8, 66-73. https://doi.org/10.18227/1982-8470ragro.v8i1.1310

[16] Bonfim-Silva, E.M., de Oliveira, J.R., de Anicesio, E.C. and da Silva, T.J.A. (2016) Teor de clorofila e desenvolvimento de feijão guandu adubado com fosfato natural reativo em Latossolo do Cerrado. Revista Agrarian, 9, 248-253.

[17] Bonfim-Silva, E.M., Silva, T.J.A., Cabral, C.E.A., Gonçalves, J.M. and Pereira, M.T.J. (2011) Produção e morfologia da leguminosa java submetida a adubação fosfatada. Enciclopédia Biosfera, 7, 1-10.

[18] Bonfim-Silva, E.M., Guimarães, S.L., Silva, J.R., Neves, L.C.R. and Silva, T.J.A. (2012) Desenvolvimento e produção da crotalária adubada com fosfato natural reativo em Latossolo do Cerrado. Enciclopédia Biosfera, 8, 347-357.

[19] Chien, S.H. and Menon, R.G. (1995) Factors Affecting the Agronomic Effectiveness of Phosphate Rock for Direct Application. Fertilizer Research, 41, 227-234. https://doi.org/10.1007/BF00748312

[20] Novais, R.F. and Smyth, T.J. (1999) Fósforo em solo e planta em condições tropicais. Universidade Federal de Viçosa, Viçosa, 399 p.

[21] Siqueira, J.O., Andrade, A.T. and Faquim, V. (2004) O papel dos microrganismos na disponibilização e aquisição de fósforo pelas plantas. In: Yamada, T. and Abdalla, S.R.S., Eds., Fósforo na agricultura brasileira, Piracicaba, Potafos, 117-149.

[22] Argenta, G., da Silva, P.R.F. and Bortolini, C.G. (2001) Clorofila na folha como in- 
dicador de nitrogênio em cereais. Ciência Rural, Santa Maria, 31, 715-722. https://doi.org/10.1590/S0103-84782001000400027

[23] Barbieri Júnior, E. (2009) Características estruturais, teores de clorofila e suas relações com o nitrogênio foliar e a biomassa em capim-Tifton 85. Dissertação, Mestrado em Zootecnia-Universidade Federal Rural do Rio de Janeiro, Rio de Janeiro.

[24] Silva, E.F.L., Araujo, A.S.F., Santos, V.B., Nunes, L.A.P.L. and Carneiro, R.F.V. (2010) Fixação biológica do N2 em feijão-caupi sob diferentes doses e fontes de fósforo solúvel. Bioscience Journal, 26, 394-402.

[25] Marschner, P. (2012) Marschner's Mineral Nutrition of Higher Plants. 3rd Edition, Academic Press, Cambridge, 649 p.

[26] Bloom, A.J., Sukrapanna, S.S. and Warner, R.L. (1992) Root Respiration Associated with Ammonium and Nitrate Absorption and Assimilation by Barley. Plant Physiology, Lancaster, 99, 1294-1301. https://doi.org/10.1104/pp.99.4.1294

[27] de Oliveira, T.C., Silva, J., dos Santos M.M., Cancellier, E.L. and Fidelis, R.R. (2014) Desempenho agronômico de cultivares de feijão em função da adubação fosfatada no sul do estado do Tocantins. Revista Caatinga, Mossoró, 27, 50-59.

[28] Taiz, L. and Zeiger, E. (2006) Fisiologia Vegetal. 3rd Edition, Artmed, 719 p. 